\title{
Concept of Teaching
}

\section{OPEN ACCESS}

Volume: 7

Issue: 2

Month: March

Year: 2019

ISSN: $2320-2653$

Received: 24.02.2019

Accepted: 09.03.2019

Published: 17.03.2019

\section{Citation:}

Isola Rajagopalan. "Concept of Teaching." Shanlax International Journal of Education, vol. 7, no. 2, 2019, 5-8.

DOI:

https://doi.org/10.34293/ education.v7i2.329

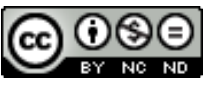

This work is licensed under a Creative Commons AttributionNonCommercialNoDerivatives 4.0 International License

\author{
Isola Rajagopalan \\ Principal (Retired) \\ District Institute of Educational Training (DIET), Tirumagalam, TamilNadu, India
}

\begin{abstract}
Edmund Amidon defined teaching as "an interactive process, primarily involving classroom talk which takes place between teacher and pupil and occurs during certain definable activities". Davis et al., Gagne et al. have contributed significantly in defining this concept and their views could be summarized as follows: Teaching is a scientific process, and its major components are content, communication and feedback. The teaching strategy has a positive effect on student learning. It is always possible to modify, improve and develop. The new teaching-learning activities, and hence the flexibility is in-built into the system; and "The terminal behaviour of the learner in terms of have pointed out that the entire structure of teaching has four steps such as Planning of teaching, Organization of teaching, Identification of suitable teaching and Managing teaching. The article deals with characteristics and related activities concerned with teaching.
\end{abstract}

Keywords: Defining planning of teaching, organisation of teaching, identification of suitable teaching, managing teaching, characteristics related activities

\section{Introduction}

When a person imparts information or skills to another, it is common to describe the action as teaching. Imparting may mean to share experiences or communicating information, for instance, lecture. Teaching is regarded as both an art or science. As an art, it lays stress on the imaginative and artistic abilities of the teacher in creating a worthwhile situation in the classroom to enable students to learn. As a science, it sheds light on the logical, mechanical, or procedural steps to be followed to attain an effective achievement of goals. Different educationists hold different ideas regarding the concept of teaching.

"Teaching is intimate contact between a more mature personality and a less mature one which designed to further the education of the latter". Morrison (1934), Dewey (1934) expressed this concept of teaching by an equation. "Teaching is learning as selling is to buying".

In the words of John Brubacher (1939), "Teaching is arrangement and manipulation of a situation in which there are gaps or obstructions which an individual will seek to overcome and from which he will learn in the course of doing so". B.O. Smith defined teaching as "Teaching is a system of actions intended to induce learning".

According to Gage (1963), "Teaching is a form interpersonal influence aimed at changing the behaviour potential another person”. Smith in 1963 further extended the definition of teaching Teaching is a system of actions involving an agent, an end in view and a situation including two sets of factors those over which the agent has no control (class size, characteristics of pupils, physical facilities, etc.) and those which he can modify (such as techniques and strategies of teaching. 
Edmund Amidon (1967) defined teaching as "an interactive process, primarily involving classroom talk which takes place between teacher and pupil and occurs during certain definable activities".Davis et al. (1962), Gagne et al. (1974) and Gage (1978) have contributed significantly to defining this concept, and their views could be summarized as follows:

Teaching is a scientific process, and its major components are content, communication and feedback. The teaching strategy has a positive effect on student learning.

It is always possible to modify, improve and develop.the new teaching-learning activities, and hence the flexibility is in $\neg$ built into the system; and "The terminal behaviour of the learner in terms of learning structures can be established by appropriate teaching environments.

Davis and Glaser (1962) have pointed out that the entire structure of teaching has four steps

'Step-I: Planning of teaching which includes content analysis, identification and writing of objectives.

Step-2: Organization of teaching which indicates the teaching strategies for achieving the objectives of teaching.

Step-3: Identification of suitable teachinglearning strategies for effective communication of content.

Step-4: Managing teaching-learning, whereby the focus is on the assessment of the learning objectives in terms of student performance, and this forms the feedback to teacher and students.

Robertson (1987) indicated that "Teaching is a generic term which denotes actions undertaken with the intention of bringing about learning in another".

The International Encyclopedia of Teaching and Teacher Education) have classified the concept of teaching into three categories:

1. Teaching as success signifies that learning is implicated in teaching. Teaching entails learning and can be defined as an activity which necessarily affects learning.

2. Teaching as an intentional activity means that teaching may not logically imply learning, but it can be anticipated that will result in learning.
3. Teaching as normative behaviour denotes action undertaken with the intention of bringing about learning another. It designates a family of activities: training and instructing are primary members and indoctrination

(Green, 1968). Training consists of activities that shape skills and other behaviours while instruction and indoctrination go with activities which induce knowledge and beliefs.

Teaching can be conceptualized as a form of problem-solving and decision - making which has many properties in common with the work of physicians. This conceptualization has led to a body of research which has investigated the decision - making of teaching focusing in particular on the information about pupils that teachers use to make decisions and the way they tailor instruction to individual pupil needs (Calderhead, 1995).

\section{Characteristics of Teaching}

The characteristics of teaching are as follows :

1. Teaching is an effective interaction between teacher and students.

2. Teaching is both arts as well as science. Teaching is an art as it calls for the exercise of talent and creativity. Teaching as science involves a repertoire of techniques, procedures and skills, that can be systematically studied, described and improved. A good teacher is one who adds creativity and inspiration to the basic repertoire.

3. Teaching has various forms, like formal and informal raining, conditioning or indoctrination, etc.

4. Teaching is dominated by the skill of communication.

5. Teaching is a tripolar process; the three poles are, educational objectives, learning experiences and change in behaviour.

6. Teaching should be well planned, and the teacher should decide the objectives, methods of teaching and evaluation techniques.

7. Teaching is suggesting and not dictating.

8. Good teaching is democratic, and teacher respects the students, encourages them to ask questions, answer questions and discuss things. 
9. Teaching provides guidance, direction and encouragement to the students.

10. Teaching is a cooperative activity and teacher should involve students in different classroom activities, such as organization, management, discussion, recitation and evaluation of results.

11. Teaching is kind and sympathetic, and a good teacher develops emotional stability among children.

12. Teaching is remedial, and the teacher must solve the learning problems of students.

13. Teaching helps children to make adjustments in life.

14. Teaching is a professional activity that helps to bring about harmonious development of children.

15. Teaching stimulates students' power of thinking and directs them towards selflearning.

16. Teaching can be observed, analyzed and evaluated.

17. Teaching is a specialized task and may be taken as a set of component skills for the realization of a specified set of instructional objectives.

\section{Teaching and Related Activities}

Exponents of Education have analyzed the concept o teaching and have essayed to differentiate teaching from related concepts such as training, conditioning and indoctrination. Teaching denotes action undertaken with the intention of bringing about learning in another. In this way, teaching is distinguished from mere telling or showing. Teaching involves face to face encounter, and the teacher's actions are conducive to bringing about student's learning. Normally, teaching acts fall within a range of activities that covers explaining, describing, demonstration exemplifying, guiding, etc... By "education" in this context is meant specific information of thought, feeling and action distinct from mere socialization. And the goal of educations is the development of critical reflective agents. It is in this context that teaching is distinguished from related activities such as training, conditioning and indoctrination.
Training is used less frequently than either conditioning indoctrination. The focus of training is on the development of skill on knowing-how rather than knowing that. Sometimes training reserved for use in the context of the teaching of routine tasks which allow total mastery. Teaching someone a skill requires developing the learner's capacity to respond to the unexpected, to understand what he or she is doing and why to be intelligent and reflective in the exercise of his or her skill.

Conditioning, when compared with teaching, is normally operant conditioning and not classical conditioning. Operant conditioning may seem to be simply a systematic form of training and hence teaching. Common school practices such as giving rewards for good behaviour can be described as setting up a situation in which a reinforcer depends upon the occurrence of a response, and that is the procedure for operant conditioning. Conditioning, in this sense, will have taken place if the probability of the desired response in the particular circumstances increases because of its association in the experience of the child with the positive reinforcer. A child's behaviour could be altered through conditioning without the child being aware of the change or having any notion of why behaving in this way might be appropriate in? The particular circumstances. Processes which by-pass human rationality are generally held to be unacceptable in a programme of education. Such processes seem less like a form of teaching and more like something resorted to when normal instruction fails. On the other hand, such rational processes as a person's learning some fact by reading or hearing statements in its favour and evaluating the evidence can be described as a process of operant conditioning. In this sense, teaching is not incompatible with conditioning students but only with some ways of doing so.

Indoctrination, in its generic sense, is considered as synonymous with teaching. Etymologically, indoctrination is related to the teaching of doctrines. A doctrine is a system of beliefs that provide an explanation or interpretation of the world and indicates how humans ought morally to act in light of the general features of existence that the system has identified. 
To conclude, it may be said that, teaching should not only aim at encouraging beliefs which are supported by the evidence but also at developing the power of students to gather the evidence; assess its adequacy for themselves. A programme of education may include the acquisition of the most reliable methods humans have developed for discovering the truth about themselves and the world When teaching skills, the educator makes the students aware of reasons for what they are doing and encourages them to be intelligent and reflective in the exercise of their skills. And though the environment may shape the behaviour of students teachers expect students to act because of perceptions of what they ought to do. It is essential to prepare the students for life by developing their capacity, intelligent freedom of choice rather than simply acquiring thought, feeling and action possessed by the learners (Rober 1987).

\section{References}

Grasha, Anthony (2010). “A Matter of Style: The Teacher as Expert, Formal Authority, Personal Model, Facilitator, and Delegator, College Teaching". 42: 142-149.

J., Savignon, Sandra (1997-01-01). Communicative competence: theory and classroom practice: texts and contexts in second language learning. McGraw-Hill. ISBN 9780070837362. OCLC 476481905.

Bolak, K., Bialach, D., \& Dunphy, M. (May 2005). Standards-based, thematic units integrate the arts and energize students and teachers. Middle School Journal, 31(2), 57-60.
Barton, K.C. \& Smith, L.A. (September 2000). Themes or motifs? Aiming for coherence through interdisciplinary outlines. The Reading Teacher, 54(1), $54-63$.

Gatewood, T. (March 1998). How valid is integrated curriculum in today's middle school? Middle School Journal, 29(4), 38 - 41

Craig, Leon Harold (2003). Of Philosophers and Kings: Political Philosophy in Shakespeare's Macbeth and King Lear. Toronto: University of Toronto Press. ISBN 978-0-8020-8605-1

Goodman, Lenn Evan (1999). Jewish and Islamic Philosophy: Crosspollinations in the Classic Age. Edinburgh University Press. pp. 25-6.

Bentley, G.E. (1961). Shakespeare: A Biographical Handbook. New Haven: Yale University Press. ISBN 978-0-313-25042-2. OCLC 356416.

Levenson, Jill L., ed. (2000). Romeo and Juliet. Oxford: Oxford University Press. ISBN 9780-19-281496-8.

Park, Katherine; Daston, Lorraine, eds. The Cambridge history of science. Cambridge, England: Cambridge University Press. p. 736. ISBN 0-521-57244-4.

Birch, William John (1848). An Inquiry into the Philosophy and Religion of Shakspere. London: C Mitchell. OCLC 162952347.

Chitwood, Ava, (2004). Death by philosophy : the biographical tradition in the life and death of the archaic philosophers Empedocles, Heraclitus, and Democritus. Ann Arbor: University of Michigan Press. p. 80. ISBN 0472113887. OCLC 54988783.

\section{Author Details}

Dr.Isola Rajagopalan, Principal (Retired),

District Institute of Educational Training (DIET), Tirumagalam, TamilNadu, India 